\title{
Project Plan Remote Target Fabrication Refurbishment Project
}

August 31, 2009 
Table of Contents

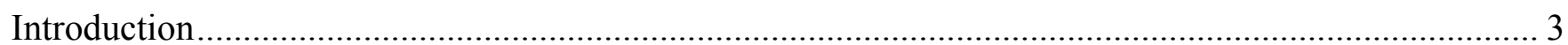

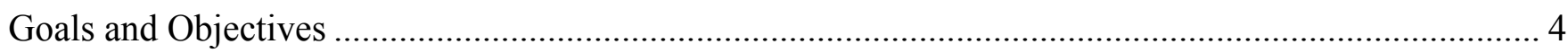

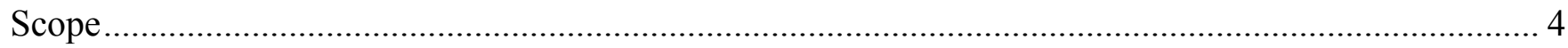

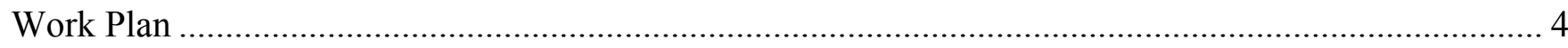

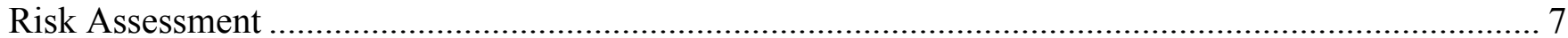

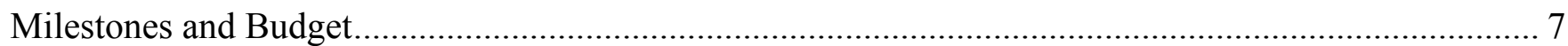

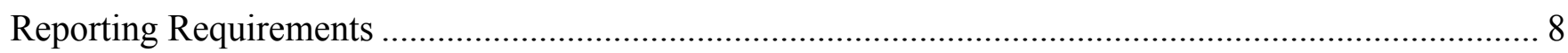

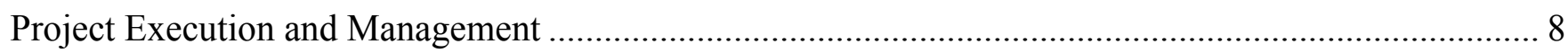

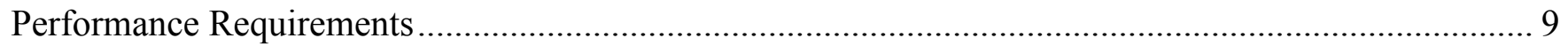




\section{Introduction}

\section{$\underline{\text { Purpose of Plan }}$}

This project plan provides the definition of the Remote Target Fabrication Refurbishment Project, including the:

- Goals and objectives

- Scope and expectations

- Project budget

- Roles and responsibilities

- Constraints and assumptions

- Work breakdown structure and timeline

- Milestones and deliverables

- Reporting Requirements

\section{Background}

In early FY2009, the DOE Office of Science - Nuclear Physics Program reinstated a program for continued production of ${ }^{252} \mathrm{Cf}$ and other transcurium isotopes at the Radiochemical Engineering Development Center (REDC) at Oak Ridge National Laboratory (ORNL). The FY2009 major elements of the workscope are as follows:

- Recovery and processing of seven transuranium element targets undergoing irradiation at the High Flux Isotope Reactor (HFIR) at ORNL

- Development of a plan to manufacture new targets for irradiation beginning in early- to mid-FY10 to supply irradiated targets for processing Campaign 75 (TRU75)

- Refurbishment of the target manufacturing equipment to allow new target manufacture in early FY10

The ${ }^{252} \mathrm{Cf}$ product from processing Campaign 74 (recently processed and currently shipping to customers) is expected to supply the domestic demands for a period of approximately two years. Therefore it is essential that new targets be introduced for irradiation by the second quarter of FY10 (HFIR cycle 427 ) to maintain supply of ${ }^{252} \mathrm{Cf}$; the average irradiation period is $\sim 10 \mathrm{HFIR}$ cycles, requiring about 1.5 calendar years.

The strategy for continued production of ${ }^{252} \mathrm{Cf}$ depends upon repairing and refurbishing the existing pellet and target fabrication equipment for one additional target production campaign. This equipment dates from the mid-1960s to the late 1980s, and during the last target fabrication campaign in 20052006, a number of component failures and operations difficulties were encountered. It is expected that following the target fabrication and acceptance testing of the targets that will supply material for processing Campaign 75 a comprehensive upgrade and replacement of the remote hot-cell equipment will be required prior to subsequent campaigns. Such a major refit could start in early FY 2011 and would take about 2 years to complete. 
Scope and cost estimates for the repairs described herein were developed, and authorization for the work was received in July 2009 under the Remote Target Fabrication Refurbishment Task of the Enhanced Utilization of Isotope Facilities project (Project Identification Code 2005230) funded by the American Recovery and Reinvestment Act of 2009.

\section{Goals and Objectives}

The goal of this project is to recover the capability to produce 4-5 curium targets for the irradiation period starting with HFIR cycle 427, currently scheduled to begin $2 / 17 / 10$. Assuming success, the equipment would then be used to fabricate 6-7 additional targets to hold for the next irradiation campaign specified by the program. Specific objectives are the return to functionality of the

- Cubicle 3 Pellet Fabrication Line

- Cubicle 2 Target Assembly equipment

- Cubicle 1 Target Inspection and Final Assembly system

\section{Scope}

The scope of this project is limited to troubleshooting and repair of the remote target fabrication and acceptance testing equipment located in Building 7920 of the REDC. The various components may be repaired or replaced as needed to achieve acceptable operation. Acceptable operation is defined as operation adequate to produce the 4-5 target rods required for the TRU75 processing campaign, meeting the current Cf target specifications [R. W. Hobbs, "Cm Target Irradiations," ORNL Experimental Authorization Bases Document: EABD-HFIR-2001-01A, October 3, 2005]. This project is not expected to perform a comprehensive upgrade and replacement of the remote hot cell equipment, which will be required for subsequent campaigns. This project is not tasked with actual fabrication of the 4-5 target rods required for TRU75. The work to fabricate targets and perform acceptance testing will be performed under the Cf Program.

\section{Work Plan}

An assessment of the remote hot cell equipment for pellet and target production was performed to support the project cost and schedule estimates. The work plan for this project addresses the repair needs in each of the three unit operations required to fabricate pellets, assemble the targets, and perform target inspection and acceptance testing. Figure 1 shows the tasks required to produce a target meeting the specifications. The general approach for this repair project is to first test the equipment to determine the current level of functionality. If performance is not satisfactory, then in-cell repair and/or parts replacement will be attempted. If in-cell repair attempts are unsuccessful, then the equipment will be decontaminated, removed from the cell and repair attempted in glovebox maintenance facilities. If the desired level of performance is still not achieved, then replacement equipment will be procured and installed in-cell. It should be noted that owing to the age and specialized nature of the equipment, failure of some components could easily suspend operations for up to 3 months while replacement hardware is obtained. For those components posing a significant risk of single-point failure, spare components will be obtained to minimize the delay in target fabrication should such a failure halt operations. The work plan is divided into 3 task sets, as follows. 


\section{Cubicle 3 Pellet Fabrication Line}

Cubicle 3 is outfitted with a semi-automatic pellet fabrication line, as well as a "thermal cleaning" furnace for evaporative removal of stearic acid lubricant from pellets under conditions of rough vacuum ( $\sim 635-737$ Torr) and $\sim 350^{\circ} \mathrm{C}$.

1.1. The existing furnace is a custom unit designed for a maximum operating temperature of $\sim 600^{\circ} \mathrm{C}$. At last use, the furnace performed satisfactorily at $350^{\circ} \mathrm{C}$; however, at least one of the multiple furnace heating elements is not working. The furnace will be tested to determine whether it can achieve and hold a temperature of $350^{\circ} \mathrm{C}$. If it cannot reach and hold $350^{\circ} \mathrm{C}$ a replacement filament will be purchased. If satisfactory operation following filament replacement is not achieved, a replacement furnace will be purchased and installed.

1.2. The Daedal/Compumotor control system for the semi-automated pellet fabrication equipment is presently operational, but there are no spare axis power-supply/controller units available (the manufacturer has discontinued their production); however, the contemporary Compumotor Gemini series is compatible with the present drive/automation system. Suitable unit(s) will be acquired and pre-engineered for prospective installation in order to mitigate risk of that singlepoint failure of critical equipment.

1.3. The hydraulic press dates from the $1960 \mathrm{~s}$, but is expected to be operable for an additional pellet fabrication campaign after routine maintenance. A laboratory press that can be promptly acquired and installed in the hot cell for manual operation should the existing integrated press catastrophically fail during pellet fabrication will be identified.

1.4. The powder dispensing weight measurement system in use is a one-of-a-kind system, designed and fabricated by ORNL in the 1980s. Future availability of technical support or replacement parts is unlikely (note that the strain-gauge component installed in the hot cell is replaceable and will likely continue to be commercially available). The powder dispensing weight measurement system is presently functioning properly, however any component failure will halt operations, therefore a replacement commercial off-the-shelf electronic balance and pre-engineered installation design (assume manual control of powder dispensing instead of programmed control) will be identified in the event rapid procurement action is required.

2. Cubicle 2 Target Assembly Equipment

A mechanical drive system failure of the remote target transfer arm in Cubicle 2 effectively halted target assembly in 2006 after successful fabrication of seven targets, as no funding was available for repair and continued operation. Additionally, several subsystems are dependent on deteriorated or obsolete components, constituting risks of single-point failures that would have critical consequences to the fabrication and assembly schedule.

The welding power-supply/controller used in prior target fabrication campaigns has failed. A new programmable welding system has been acquired using other programmatic funds, but has not been installed. 
A calorimeter is also installed in Cubicle 2 for measurement of actinide content in the oxide powder used in pellet fabrication as well as the completed pellets designated for target assemblies.

2.1. The remote target welder ("assembly machine") has issues of known component failures and unreliable/inconsistent performance. An initial attempt to remotely repair the assembly machine in the hot cell will be performed, limited to replacement of the roll swager, functional testing of the assembly machine, and replacement of readily accessible external components that may be found inoperable during testing (e.g., motor, solenoid). If remote repairs are inadequate, the assembly machine will be removed from the hot cell via transfer case to the decon/repair glove box for refurbishment (i.e., rebuild collet chuck with new components, inspect rotary seals and electromechanical components and replace as needed). The repaired welder will be returned to the hot cell via transfer case following reinstallation of the transfer arm.

NOTE: If the assembly machine has to be removed from the hot cell, it would be an opportune time to install a new disconnect well in the floor of Cubicle 2 to accommodate future lowering of the target assembly machine in the hot cell for improved remote operability and maintainability with master-slave manipulators (subject to schedule constraints).

2.2. An initial attempt to remotely repair the transfer arm in the hot cell will be performed to restore minimal functionality (vertical and rotary motion, grappling, and control); however, it is likely that the transfer arm will have to be removed from the hot cell via transfer case to the decon/repair glove box for refurbishment of the vertical drive pinion assembly and rotary drive system. Glove box repairs would include inspection and repair, as needed, of the counterweight spring assembly. New motors and power cables will be procured, inspected, tested and installed. The target grappling head will be evaluated to determine options for updating the electromechanical encoder and actuation drive. The repaired transfer arm will be returned to the hot cell via transfer case prior to reinstallation of the target welder. Testing will demonstrate adequate linear (vertical) and rotational range.

2.3. Install new welding power-supply/controller in Room 213 (Make-Up Area). Provide new and rerouted power and control circuits from the Upper Limited Access Area (Room 120), Control Room (Room 116), and Lab 214 to the unit location in Room 213.

2.4. Determine procedural updates required for compliance with revised ORNL standards for weld inspection. Perform updates and issue revised welding procedures as needed.

2.5. Perform functional testing and calibration of the calorimeter system in Cubicle 2 .

3. Cubicle 1 Target Inspection and Final Assembly

3.1. Remotely troubleshoot and repair the transfer arm rotary drive system. 
3.2. Replace He leak detector in Room 213 and selected piping and vacuum valves (new leak detector available - acquired by another program). Flush vacuum lines from Room 213 to Cubicle 1 leak test station to remove volatile contaminants. Replace in-line HEPA filters. Determine procedural updates required for compliance with revised ORNL standards for leak testing.

3.3. Inspect staking machine (used for installation of coolant shroud on welded targets). Repair as needed.

3.4. Functionally test radiography system in Cubicle 1. Design and fabricate equipment components for replacement of x-ray tube in Cubicle 1, including high voltage cables and cubicle bulkhead connectors. Develop work plan for removal of hot cell shielding blocks and system installation, including ALARA assessment and engineering/procurement of temporary shielding for mitigation of direct radiation dose risk to workers. Evaluate computed radiography imaging alternative to film imaging and procure/deploy as appropriate. Determine procedural updates required for compliance with revised ORNL standards for weld inspection.

NOTE: Evaluate alternative stand-alone target radiography system for location external to the hot cell, including operational logistics and schedule/cost implications for prospective amendment of facility safety basis documents.

Error! Reference source not found. The schedule is driven by requirement to fabricate targets for insertion in HFIR Cycle 427. Targets must be approved and delivered to HFIR by 29Jan10 (start of End-of-Cycle 426).

\section{Risk Assessment}

The refurbishment sequence and schedule are strategically leveraged to meet the HFIR Cycle 427 insertion goal. However, meeting that goal is predicated on successful outcomes of aggressive tactics in the refurbishment effort, and there is an increased risk of failure to achieve full target fabrication functionality with each attempted remediation. Potential impacts of delayed target insertion until HFIR Cycle 428 are a 42 -day delay in ${ }^{252} \mathrm{Cf}$ recovery for the intended 10 -cycle irradiation, or a decrease in ${ }^{252} \mathrm{Cf}$ production for an abbreviated 9-cycle irradiation (with no recovery schedule delay).

\section{Milestones and Budget}

The budget authority for this project is $\$ 900,000$. This funding may be used in conjunction with other funding as necessary to complete the project, but tracking and reporting must be separate to meet the reporting requirements of the Recovery Act and the Guidance Letter/Work Authorization document [From Eugene A. Henry to Gerald G. Boyd, Subject: American Recovery and Reinvestment Act approved Funding Program Guidance - Isotope Production and Distribution Fund - REVISED WAS, July 9, 2009]. The work breakdown structure, charge account numbers and milestones are shown in Table 1 and Table 2. The funding structure is shown in Figure 2. 
Table 1. Work Breakdown Structure

\begin{tabular}{|l|l|l|l|}
\hline Task No. & $\begin{array}{l}\text { SAP } \\
\text { Account }\end{array}$ & Title & $\begin{array}{l}\text { Budget } \\
\text { Authority }\end{array}$ \\
\hline EUIF.01.02 & 3641ARTM & Project Management & $\$ 100,000$ \\
\hline EUIF.01.02 & 3641 ARTT & $\begin{array}{l}\text { Target Fabrication Repair and } \\
\text { Testing }\end{array}$ & $\$ 300,000$ \\
\hline EUIF.02.02 & J9340K00 & $\begin{array}{l}\text { Target Fabrication Equipment - } \\
\text { Capital }\end{array}$ & $\$ 500,000$ \\
\hline
\end{tabular}

Table 2. Project Milestones

\begin{tabular}{|l|l|c|}
\hline Task No. & ORNL - Remote Target Fabrication Refurbishment & Date \\
\hline EUIF.01.02 & Issue Project Plan and initiate refurbishment work & Aug-09 \\
\hline EUIF.02.02 & $\begin{array}{l}\text { Target fabrication equipment operational for use in Cf } \\
\text { Campaign 74 }\end{array}$ & Mar-10 \\
\hline EUIF.02.02 & Install target acceptance testing equipment & Jun-10 \\
\hline EUIF.02.02 & Commission Updated Target System & Jul-10 \\
\hline
\end{tabular}

\section{Reporting Requirements}

Weekly reporting is required using the template provided by the ORNL ARRA Project Controls team (Chip Slate is the contact for this project). An example of this Excel spreadsheet reporting template is shown in Figure 3. The report is due to Chip Slate by close of business each Tuesday. Detailed weekly progress reports are not required, only very high level progress notes are needed. A letter to the Federal Program Manager to document completion of the milestones is not required. The milestone reporting requirements are satisfied by marking the box on the form with a "Yes" or "No" in the "Recovery Act Milestones" section of the report template.

Monthly highlights will be provided to the ORNL Isotopes Program Manager on the last day of each calendar month. It is anticipated that these highlights will be included with other Isotopes Program monthly highlights for submission to the Federal Program Manager.

\section{Project Execution and Management}

The primary responsibility for planning and execution of the project resides with the Principal Investigator (PI), Robin Taylor. Providing technical and operational support will be Andy Souders (Engineering Technical Specialist) and Frank Riley (Sr. Technician).

Gary Bell is responsible for the management of this project. This role includes maintaining cognizance for developing and maintaining the project plans, executing on time and within budget, and ensuring that the project complies with the reporting requirements for the ARRA funding.

Chip Slate is the Project Controller assigned by the ORNL ARRA Project Controls team. His responsibilities include tracking cost and schedule, working with the project manager to establish and secure approval for a work breakdown structure and account structure meeting ORNL requirements for ARRA funded projects. 
Jeff Binder is the ORNL Isotopes Program Manager providing management, budget and technical oversight and serving as the ONRL Point of Contact for all Isotope Program activities.

John Pantaleo is the Federal Program Manager with overall responsibility for successful project execution, oversight, and integration with other program activities.

Contact information for the project team is in Table 3.

Table 3. Contact Information

\begin{tabular}{|l|l|l|l|}
\hline Role & Name & Phone Number & Email Address \\
\hline Project Manager & Gary Bell & $865-241-4400$ & bellgl@ornl.gov \\
\hline $\begin{array}{l}\text { Engineering } \\
\text { Technical Specialist }\end{array}$ & Andy Souders & $865-241-3388$ & soudersa@ornl.gov \\
\hline Senior Technician & Frank Riley & $865-576-8165$ & rileyfdjr@ornl.gov \\
\hline $\begin{array}{l}\text { Principal } \\
\text { Investigator }\end{array}$ & Robin Taylor & $865-576-2314$ & taylorrd@ornl.gov \\
\hline Project Controller & Chip Slate & $865-241-8341$ & slatear@ornl.gov \\
\hline $\begin{array}{l}\text { ORNL Isotopes } \\
\text { Program Manager }\end{array}$ & Jeff Binder & $865-576-3879$ & binderj1@ornl.gov \\
\hline $\begin{array}{l}\text { Federal Program } \\
\text { Manager }\end{array}$ & John Pantaleo, Jr. & $301-903-2525$ & john.pantaleo@science.doe.gov \\
\hline $\begin{array}{l}\text { Federal Program } \\
\text { Financial Advisor }\end{array}$ & Joanne Wolfe & $301-903-6949$ & joanne.wolfe@science.doe.gov \\
\hline
\end{tabular}

\section{Performance Requirements}

The project performance requirements for the Remote Target Fabrication Refurbishment project taken from the Guidance Letter/WAS are listed in Table 4.

Table 4. DOE-NP project performance requirements

\begin{tabular}{|l|l|}
\hline Due Date & Performance Requirement \\
\hline 4QFY09 & Issue Project Plan and initiate refurbishment work. \\
\hline 2QFY10 & Target fabrication equipment operational for use in Cf Campaign 74. \\
\hline 3QFY10 & Install target acceptance testing equipment \\
\hline 4QFY10 & Commission updated Target System. \\
\hline
\end{tabular}


Figures

\section{Target Fabrication}

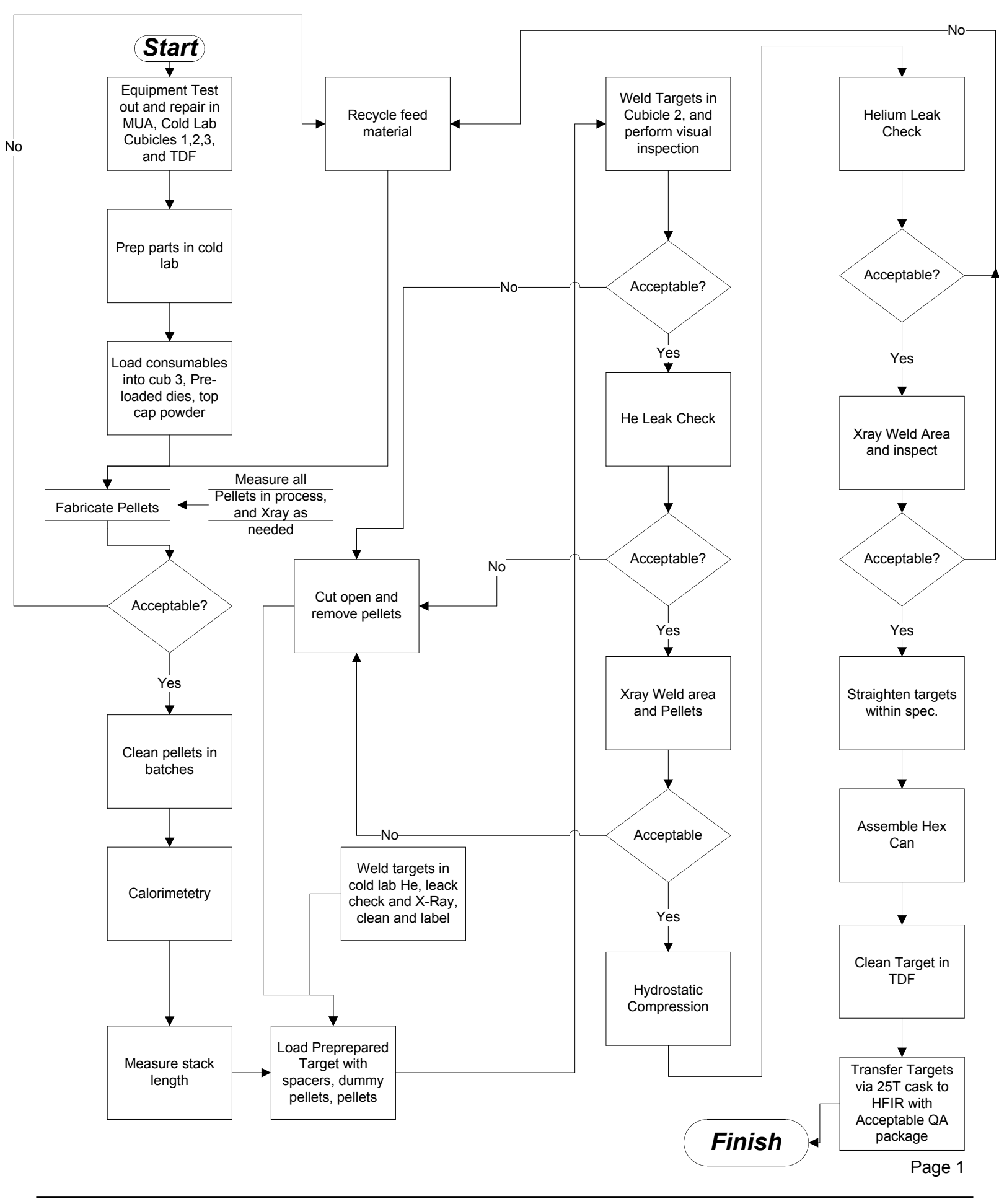

Figure 1. Target fabrication flow diagram. 


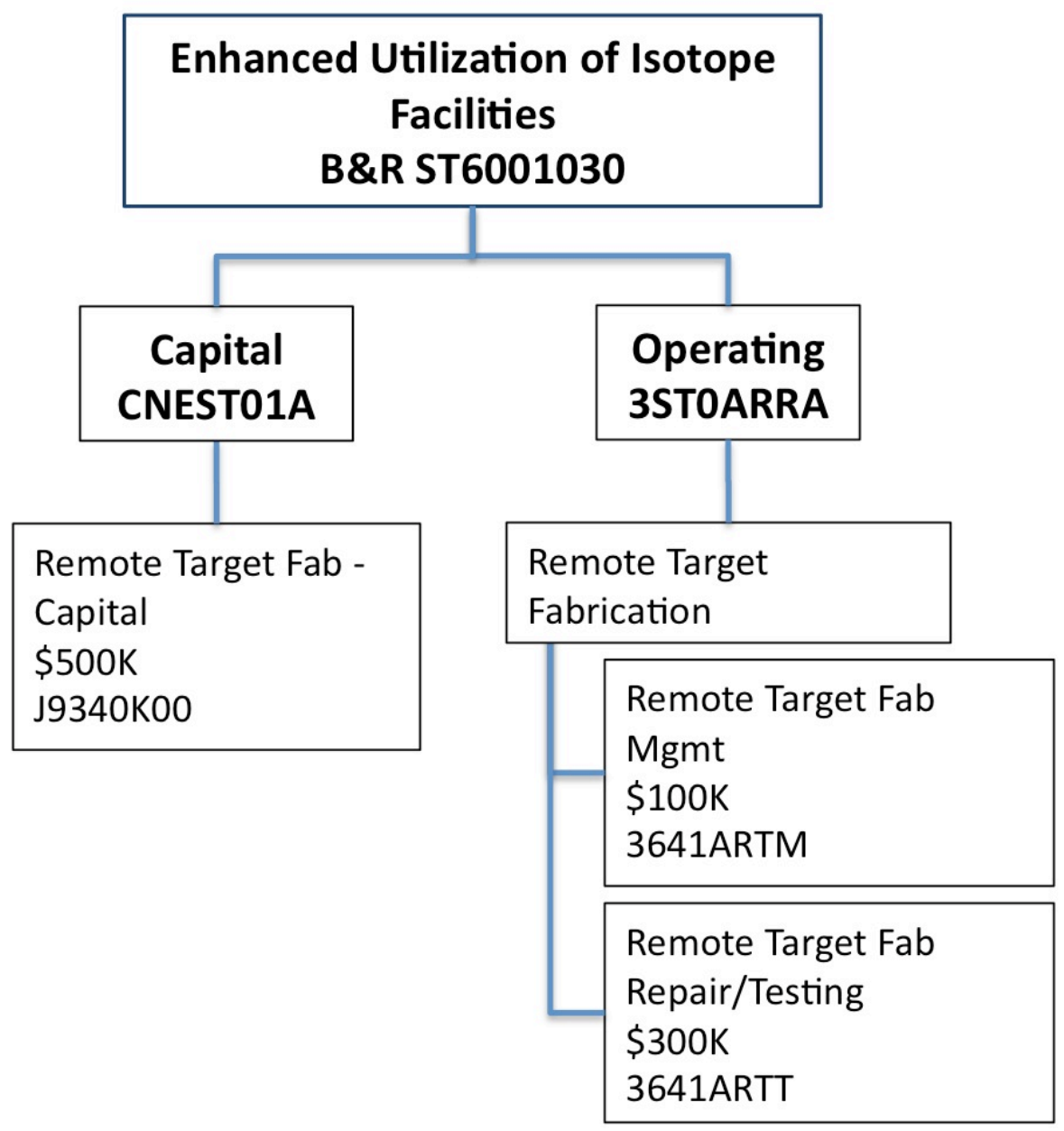

Figure 2. Diagram of the project funding structure with budget authority and account numbers. 


\begin{tabular}{|c|c|c|c|c|c|}
\hline$\diamond$ & A & B & C & D & $\mathbf{F}$ \\
\hline 1 & \multicolumn{5}{|c|}{ Weekly Recovery Act Reporting: DOE Office of Science } \\
\hline 2 & \multicolumn{5}{|c|}{ Project Name: Enhanced Utilization of Isotope Facilities (2005230) } \\
\hline 3 & \multicolumn{2}{|l|}{ Reporting Period: 08/07/09 - 08/13/09 } & & & \\
\hline 4 & \multicolumn{2}{|l|}{ Laboratory M\&O Contractor: Oak Ridge National Laboratory } & & & \\
\hline 5 & \multicolumn{2}{|l|}{ WAS Number: ST/OR41/9/ARRA-3 } & & & \\
\hline 6 & Laboratory POC: Jeffery Binder (865) 576-3879 & & & & \\
\hline 7 & \multicolumn{2}{|l|}{ SC Program POC: Eugene Henry (301) 903-3613 } & & & \\
\hline 8 & \multicolumn{2}{|l|}{ Site Office POC: Sherman Martin (865) 576-4522 } & & & \\
\hline 9 & \multicolumn{2}{|l|}{ SC Budget Office POC: Andrea Condrad (301) 903-3310 } & & & \\
\hline 10 & \multicolumn{2}{|l|}{ Total Funding Under this WAS: $\$ 3.9 \mathrm{M}$} & & & \\
\hline 11 & \multicolumn{5}{|l|}{ FUNDING OBLIGATIONS AND OUTLAYS } \\
\hline 12 & \multicolumn{2}{|l|}{ Funds Obligated This Reporting Period } & & Funding Outlays to Date & SO \\
\hline 13 & \multirow{2}{*}{\multicolumn{2}{|c|}{$\begin{array}{l}\text { Funds Obligated to Date } \\
\text { Total Indirect Costs to Date }\end{array}$}} & & & \\
\hline 14 & & & & & \\
\hline 15 & \multicolumn{4}{|l|}{ JOBS } & \\
\hline 16 & & & \multicolumn{2}{|c|}{ Prime Contract } & First Tier Sub-contracts \\
\hline 17 & \multirow{2}{*}{\multicolumn{2}{|c|}{$\begin{array}{l}\text { Jobs Created to Date } \\
\text { Jobs Retained to Date }\end{array}$}} & & 0 & \multirow{2}{*}{$\begin{array}{ll}0 \\
0 \\
\end{array}$} \\
\hline 18 & & & & & \\
\hline 19 & \\
\hline 20 & & & & & \\
\hline 21 & $\begin{array}{l}\text { RECOVERY ACT MILESTONES } \\
\text { Recovery Act Milestones }\end{array}$ & Date & \multicolumn{2}{|c|}{ Progress Towards Next Milestones } & $\begin{array}{l}\text { Completed } \\
\text { (Yes/No) }\end{array}$ \\
\hline 22 & $\begin{array}{l}\text { Remote Target Fabrication Refurbishment: } \\
\text { Issue Project Plan and initiate refurbishment work }\end{array}$ & Aug-09 & \multicolumn{2}{|c|}{$\begin{array}{l}\text { On schedule } \\
\text { Internal ORNL WBS and SAP charge } \\
\text { accounts approved. Began drafting } \\
\text { Project Plan. New hire interviewed. }\end{array}$} & No \\
\hline 23 & $\begin{array}{l}\text { Stable Isotope Purchase: } \\
\text { Issue Purchase Requisition with sole source letters to } \\
\text { foreign suppliers }\end{array}$ & Aug-09 & \multicolumn{2}{|c|}{$\begin{array}{l}\text { On schedule } \\
\text { Internal ORNL WBS and SAP charge } \\
\text { accounts approved. Began preparation of } \\
\text { purchase requistion. }\end{array}$} & No \\
\hline 24 & $\begin{array}{l}\text { Stable Isotope Purchase: } \\
\text { Issue Purchase Order for Stable Isotope Purchase }\end{array}$ & Sep-09 & \multicolumn{2}{|c|}{$\begin{array}{l}\text { On Schedule } \\
\text { Internal ORNL WBS and SAP charge } \\
\text { accounts approved. }\end{array}$} & No \\
\hline 25 & $\begin{array}{l}\text { PaR Remote Handling System Replacement: } \\
\text { Issue Project Plan }\end{array}$ & Oct-09 & \multicolumn{2}{|c|}{$\begin{array}{l}\text { On Schedule } \\
\text { Project kickoff meeting scheduled for } \\
\text { 14Aug09. }\end{array}$} & No \\
\hline \multicolumn{6}{|l|}{26} \\
\hline 27 & Additional Notable Milestones & Date & \multirow{2}{*}{\multicolumn{2}{|c|}{$\begin{array}{l}\text { Progress Towards Next Milestone } \\
\text { N/A }\end{array}$}} & $\begin{array}{l}\text { Completed } \\
\text { (Yes/No) }\end{array}$ \\
\hline 28 & (2) & N/A & & & \\
\hline 29 & & & & & \\
\hline 30 & PERFORMANCE METRICS & & & & \\
\hline 31 & \begin{tabular}{|cc}
$\begin{array}{c}\text { Recovery Act Milestones } \\
\text { Program Milestone Table) }\end{array}$ & (From SC \\
\end{tabular} & FY Quarter & Pro & ess Towards Next Milestones & $\begin{array}{c}\text { Completed } \\
\text { (Yes/No) }\end{array}$ \\
\hline 32 & $\begin{array}{l}\text { - Issue Purchase Order for stable isotopes } \\
\text { - Initiate work on Remote Target Fabrication Refurbishment }\end{array}$ & $4 Q$ FYO9 & On sch & & No \\
\hline 33 & - Initiate PaR Remote Handling System Replacement & $1 Q F Y 10$ & On sch & & No \\
\hline
\end{tabular}

Figure 3. Example of the ARRA Reporting Form. 